\title{
Front Matter: Volume 7280
}

, "Front Matter: Volume 7280," Proc. SPIE 7280, Seventh International Conference on Photonics and Imaging in Biology and Medicine, 728001 (17 March 2009); doi: 10.1117/12.827129

SPIE. Event: Photonics and Optoelectronics Meetings, 2008, Wuhan, China 


\title{
PROGRESS IN BIOMEDICAL OPTICS AND IMAGING
}

Vol. 10, No. 42

\section{Seventh International Conference on \\ Photonics and Imaging in Biology and Medicine}

\author{
Qingming Luo \\ Lihong V. Wang \\ Valery V. Tuchin \\ Editors
}

\section{4-27 November 2008 \\ Wuhan, China}

Organized by

Britton Chance Center for Biomedical Optics (China) - Wuhan National Laboratory for Optoelectronics (China) • Key Laboratory of Biomedical Photonics, Ministry of Education (China)

Sponsored by

Britton Chance Center for Biomedical Optics (China) - Wuhan National Laboratory for Optoelectronics (China) • Key Laboratory of Biomedical Photonics, Ministry of Education (China) • Virtual Research Center of Biomedical Photonics, Ministry of Education (China) • Hubei Bioinformatics and Molecular Imaging Key Laboratory (China) • Bio-Optics and Laser Medicine Committee of Chinese Optical Society (China) • Huazhong University of Science and Technology (China)

Technical Cosponsors

IBOS_International Biomedical Optics Society • Chinese Optical Society • The Biophysical Society of China

Published by

SPIE

Volume 7280

Proceedings of SPIE, 1605-7422, v. 7280

SPIE is an international society advancing an interdisciplinary approach to the science and application of light. 
The papers included in this volume were part of the technical conference cited on the cover and title page. Papers were selected and subject to review by the editors and conference program committee. Some conference presentations may not be available for publication. The papers published in these proceedings reflect the work and thoughts of the authors and are published herein as submitted. The publisher is not responsible for the validity of the information or for any outcomes resulting from reliance thereon.

Please use the following format to cite material from this book:

Author(s), "Title of Paper," in Seventh International Conference on Photonics and Imaging in Biology and Medicine, edited by Qingming Luo, Lihong V. Wang, Valery V. Tuchin, Proceedings of SPIE Vol. 7280 (SPIE, Bellingham, WA, 2009) Article CID Number.

ISSN 1605-7422

ISBN 9780819475398

Published by

SPIE

P.O. Box 10, Bellingham, Washington 98227-0010 USA

Telephone +1 3606763290 (Pacific Time) · Fax +1 3606471445

SPIE.org

Copyright (C) 2009, Society of Photo-Optical Instrumentation Engineers.

Copying of material in this book for internal or personal use, or for the internal or personal use of specific clients, beyond the fair use provisions granted by the U.S. Copyright Law is authorized by SPIE subject to payment of copying fees. The Transactional Reporting Service base fee for this volume is $\$ 18.00$ per article (or portion thereof), which should be paid directly to the Copyright Clearance Center (CCC), 222 Rosewood Drive, Danvers, MA 01923. Payment may also be made electronically through CCC Online at copyright.com. Other copying for republication, resale, advertising or promotion, or any form of systematic or multiple reproduction of any material in this book is prohibited except with permission in writing from the publisher. The CCC fee code is 1605 $7422 / 09 / \$ 18.00$.

Printed in the United States of America.

Publication of record for individual papers is online in the SPIE Digital Library.

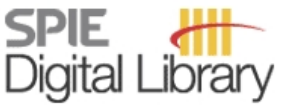

SPIEDigitallibrary.org

Paper Numbering: Proceedings of SPIE follow an e-First publication model, with papers published first online and then in print and on CD-ROM. Papers are published as they are submitted and meet publication criteria. A unique, consistent, permanent citation identifier (CID) number is assigned to each article at the time of the first publication. Utilization of CIDs allows articles to be fully citable as soon they are published online, and connects the same identifier to all online, print, and electronic versions of the publication. SPIE uses a six-digit CID article numbering system in which:

- The first four digits correspond to the SPIE volume number.

- The last two digits indicate publication order within the volume using a Base 36 numbering system employing both numerals and letters. These two-number sets start with 00, 01, 02, 03, 04, $05,06,07,08,09,0 A, 0 B \ldots 0 Z$, followed by 10-1Z, 20-2Z, etc.

The CID number appears on each page of the manuscript. The complete citation is used on the first page, and an abbreviated version on subsequent pages. Numbers in the index correspond to the last two digits of the six-digit CID number. 


\title{
Contents
}

\author{
xiii Conference Committees \\ xvii Introduction
}

\section{SEVENTH INTERNATIONAL CONFERENCE ON PHOTONICS AND IMAGING IN BIOLOGY AND MEDICINE}

728002 Mitochondrial activity and brain functions during cortical depolarization (Invited Paper) [7280-157]

A. Mayevsky, J. Sonn, Bar-llan Univ. (Israel)

728004 A temperature control system integrated with a microfluidic chip for sperm analysis (Invited Paper) [7280-125]

C. Han, R. Ma, Tsinghua Univ. School of Medicine (China) and National Engineering Research Ctr. for Beijing Biochip Technology (China); Z. Sun, Shanxi Agricultural Univ. (China); Z. Yu, National Engineering Research Ctr. for Beijing Biochip Technology (China); J. Qiao, Third Hospital of Peking Univ. (China); G. Huang, Y. Zhou, Tsinghua Univ. School of Medicine (China) and National Engineering Research Ctr. for Beijing Biochip Technology (China); J. Wang, Shanxi Agricultural Univ. (China); J. Cheng, Tsinghua Univ. School of Medicine (China) and National Engineering Research Ctr. for Beijing Biochip Technology (China)

728005 Morphological and biochemical changes after intravenous injection of gold nanoparticles [7280-163]

G. S. Terentyuk, Saratov State Univ. (Russian Federation); G. N. Maslyakova,

L. V. Suleymanova, V. B. Borodulin, Yu. S. Dudakova, Saratov State Medical Univ. (Russian Federation); N. G. Khlebtsov, B. N. Khlebtsov, Institute of Biochemistry and Physiology of Plants and Microorganisms (Russian Federation); G. G. Akchurin, I. L. Maksimova, Saratov State Univ. (Russian Federation); V. V. Tuchin, Saratov State Univ. (Russian Federation) and Institute of Precise Mechanics and Control (Russian Federation)

728006 Precisely repeating spike temporal sequences in spontaneous activity of cultured hippocampal neuronal networks on multi-electrode arrays [7280-19] L. Chen, H. Pan, Guangxi Univ. (China)

728007 Optical model for port-wine stain skin and its Monte Carlo simulation [7280-27] L. Xu, Z. Xiao, R. Chen, Fujian Normal Univ. (China); Y. Wang, Chinese PLA General Hospital (China)

728009 Application of wavelet packet transform to compressing Raman spectra data [7280-40] C. Chen, Yangtze Univ. (China); F. Peng, Tongji Hospital, Huazhong Univ. of Science and Technology (China); Q. Cheng, D. Xu, Yangtze Univ. (China)

$7280 \mathrm{OA}$ High-speed wide tuning range wavelength swept laser around $1310 \mathrm{~nm}$ for frequency domain OCT [7280-72]

M. Chen, Z. Ding, T. Wu, L. Xu, Zhejiang Univ. (China) 
7280 OB Microstructure fabrication on glasses for microfluidics [7280-93]

Q. Chen, Q. Chen, Politecnico di Torino (Italy); G. Liao, Luoyang Institute of Science and Technology (China); D. Milanese, Politecnico di Torino (Italy)

7280 OC Raman spectral data denoising based on wavelet analysis [7280-41] C. Chen, Yangtze Univ. (China); F. Peng, Tongji Hospital, Huazhong Univ. of Science and Technology (China); Q. Cheng, D. Xu, Yangtze Univ. (China)

7280 OD Evolutionary model of flexible exponential function to characterize decay pattern of OCT signal in turbid tissues [7280-95]

B. Chen, Z. Guo, South China Normal Univ. (China)

7280 OE Crushing cells in microfluidic channels and observing with optical imaging [7280-128] J. Chen, Huazhong Univ. of Science and Technology (China) and Huazhong Agriculture Univ. (China); C. Chai, Huazhong Agriculture Univ. (China); J. Wang, H. Liao, Huazhong Univ. of Science and Technology (China); H. Han, Huazhong Agriculture Univ. (China); J. Yu, Huazhong Univ. of Science and Technology (China)

7280 OF Digital techniques of classification of malignant and nonmalignant growths [7280-129] A. S. Ulyanov, Saratov State Univ. (Russian Federation)

7280 0G Detailed operation procedure of three polarized Monte Carlo programs and compulsory optimizations [7280-23]

X. Cheng, X. Wang, Shanghai Institute of Optics and Fine Mechanics (China) and Graduate School of the Chinese Academy of Sciences (China); F. Tang, P. Bu, Shanghai Institute of Optics and Fine Mechanics (China)

$7280 \mathrm{OH} \quad$ A low conductivity culture medium suitable for the evaluation of sperm motility [7280-124] R. Ma, C. Han, Tsinghua Univ. School of Medicine (China) and National Engineering Research Ctr. for Beijing Biochip Technology (China); Z. Sun, Shanxi Agricultural Univ. (China); G. Huang, Tsinghua Univ. School of Medicine (China) and National Engineering Research Ctr. for Beijing Biochip Technology (China); Z. Yu, National Engineering Research Ctr. for Beijing Biochip Technology (China); Y. Zhou, Tsinghua Univ. School of Medicine (China) and National Engineering Research Ctr. for Beijing Biochip Technology (China); J. Wang, Shanxi Agricultural Univ. (China); J. Qiao, Third Hospital of Peking Univ. (China); J. Cheng, Tsinghua Univ. School of Medicine (China) and National Engineering Research Ctr. for Beijing Biochip Technology (China)

$7280 \mathrm{Ol}$ Path integral based contour extraction method using multilevel metropolis sampling [7280-131]

Y. Sun, T. Lan, X. Fu, M. Ding, Huazhong Univ. of Science and Technology (China)

$72800 \mathrm{~J} \quad$ Fractional Er:YAG laser and its application in dermatology [7280-142]

X. Fan, Z. Li, H. Zhou, Y. He, H. Xia, Huazhong Univ. of Science and Technology (China) and Wuhan National Lab. for Optoelectronics (China)

7280 OK Practical contour segmentation algorithm for small animal digital radiography image [7280-09]

F. Zheng, G. Hui, Huazhong Univ. of Science and Technology (China) 
$7280 \mathrm{OL}$ The repair of low dose UV light-induced damage to human skin DNA in condition of trace amount $\mathbf{M g}^{2+}[7280-70]$

F. Gao, Z. Guo, C. Zheng, R. Wang, Z. Liu, P. Meng, J. Zhai, South China Normal Univ. (China)

7280 OM Effective fitting depth of measurement of tissue-simulating phantom optical properties with optical coherence tomography [7280-97]

S. Feng, K. Yuan, D. Ye, Tsinghua Univ. (China)

$72800 \mathrm{~N} \quad$ Surface-enhanced Raman spectroscopy study of the interaction of antitumoral drug Paclitaxel with human serum albumin [7280-71]

T. Yan, H. Gu, X. Yuan, J. Wu, H. Wei, South China Normal Univ. (China)

728000 Study on spherical localization based on two image sensors under complex circumstances [7280-26]

G. He, K. Huang, Beijing Institute of Technology (China); B. Yuan, Univ. of Science and Technology Beijing (China)

7280 OP Simulation and experiments for high-power laser vaporizing bio-tissue [7280-136] C. Huang, Y. Yao, X. Yan, Hubei Univ. of Technology (China); Z. Li, Wuhan National Lab. for Optoelectronics (China)

$7280 \mathrm{OQ}$ The effect of solanine on the membrane potential of mitochondria in HepG2 cells and [Ca ${ }^{2+}$ ] in the cells [7280-43]

Y. Ji, Engineering Research Ctr. of Natural Antineoplastic Drugs (China) and Harbin Univ. of Commerce (China); S. Gao, Engineering Research Ctr. of Natural Antineoplastic Drugs (China); C. Ji, Engineering Research Ctr. of Natural Antineoplastic Drugs (China) and Harbin Univ. of Commerce (China); X. Zou, Harbin Univ. of Commerce (China)

7280 OR The spectrum character of photoreaction of Hypocrellin A and cysteine [7280-42] J. Zhang, W. Liu, Y. Li, P. Zhang, Z. Yi, Y. Min, Z. Huang, L. Yao, H. LU, Honghe Univ. (China)

7280 OS Microsphere-enhanced label-free high-throughput molecular detection [7280-148] C. Deng, G. Huang, S. Xu, J. Zhu, R. Ma, C. Han, S. Chen, C. Ma, Tsinghua Univ. School of Medicine (China) and National Engineering Research Ctr. for Beijing Biochip Technology (China)

7280 OT Analysis of relationship between apoptosis and change of $\mathrm{Ca}^{2+}$ in HepG-2 induced by CSA with laser scanning confocal technology [7280-45]

Y. Ji, L. Yu, Harbin Univ. of Commerce (China) and Engineering Research Ctr. of Natural Anticancer Drugs (China)

$7280 \mathrm{OU}$ Quantity analysis of micro-organisms in bottled water [7280-96]

J. Li, X. Li, Dezhou Univ. (China)

7280 OV Application methods of infrared thermal images in the health care field of traditional Chinese medicine [7280-18]

Z. Li, South China Normal Univ. (China); X. Zhang, Biological Pharmaceutical Institute of Ezhou (China) 
$7280 \mathrm{OW}$ Correlation between the skewness and the scattering coefficient of intralipid solution [7280-31]

Z. Li, H. Li, S. Wu, S. Xie, Fujian Normal Univ. (China)

7280 0X Discussion on backscattered polarization patterns from turbid media in a layered structure [7280-47]

L. Xu, A. Cai, X. Lin, H. Li, Fujian Normal Univ. (China)

7280 OY The multiple parameter hemodynamic imaging system based on ARM [7280-137]

X. Tang, H. He, C. Jiang, P. Li, Q. Luo, Huazhong Univ. of Science and Technology (China)

$7280 \mathrm{OZ} \quad$ Impact of magnification of imaging system on laser speckle contrast imaging [7280-140]

J. Qiu, H. Zhang, P. Li, Q. Luo, Huazhong Univ. of Science and Technology (China)

728010 In vivo photoacoustic molecular imaging with targeting single-walled carbon nanotubes [7280-116]

L. Xiang, D. Xing, Y. Yuan, L. Huang, South China Normal Univ. (China)

728011 Clinical therapeutic effect of intense pulse light PhotoDerm for vascular dermatosis [7280-39] L.-J. Qiu, Fourth Military Medical Univ. (China); L.-W. Xu, Y.-Y. Li, Fourth Military Medical Univ. (China) and Qiqihar Univ. (China); J.-Q. Yang, J.-X. Qi, Fourth Military Medical Univ. (China)

728012 Meta-analysis on intravascular low energy laser therapy [7280-134]

S.-D. Zhao, T. C.-Y. Liu, Y.-F. Wang, S.-H. Liu, South China Normal Univ. (China)

728013 Nondestructive assessment of internal quality of Gannan navel orange by photodiode array spectrometer [7280-17]

X. Sun, H. Zhou, W. Zhou, Y. Liu, Jiangxi Agricultural Univ. (China)

$728014 \quad$ Image processing methods for visual prostheses based on DSP [7280-21]

H. Liu, Y. Zhao, Y. Tian, Q. Ren, X. Chai, Shanghai Jiao Tong Univ. (China)

728015 Hypocrellin B graft on activated carbon and photocatalytic oxidation of 2,3,5-trimethylphenol [7280-36]

W. Liu, Y. Li, P. Zhang, J. Zhang, Y. Min, Z. Yi, C. Zhang, M. Wu, R. Chen, Honghe Univ. (China)

$728016 \quad$ Health-promoting low level laser therapy [7280-59]

J.-Q. Yuan, T. C.-Y. Liu, J.-H. Li, X.-G. Liu, X.-Y. XU, S.-H. Liu, South China Normal Univ. (China)

728017 Homeostatic study of the effects of sportswear color on the contest outcome [7280-60] J.-Q. Yuan, T. C.-Y. Liu, R.-L. Wu, C.-X. Ruan, L.-M. He, S.-H. Liu, South China Normal Univ. (China)

728018 Study on residual stress in carbon fibres by Raman spectroscopy [7280-68] H. Liu, Q. Wang, J. Wu, C. Zhang, J. Wang, Xi'an Polytechnic Univ. (China); Y. Tang, Xi'an Univ. of Technology (China)

728019 Research on optical properties of dental enamel for early caries diagnostics using a He-Ne laser [7280-77]

J. Tang, L. Liu, S. Li, Wuhan Univ. of Science and Engineering (China) 
$72801 \mathrm{~A}$ Involvement of BimL activation in apoptosis induced by lysosomal photodamage [7280-114] L. Liu, X. Wang, H. Li, South China Normal Univ. (China)

7280 1B Randomized trial comparing exercise therapy, alternating cold and hot therapy, and low intensity laser therapy for chronic lumbar muscle strain [7280-144]

X. Liu, Huazhong Univ. of Science and Technology (China) and South China Normal Univ. (China); J. Li, South China Normal Univ. (China); T. C. Liu, Huazhong Univ. of Science and Technology (China) and South China Normal Univ. (China); J. Yuan, South China Normal Univ. (China); Q. Luo, Huazhong Univ. of Science and Technology (China)

7280 1C Development of a spectrally resolved multifocal multiphoton microscope [7280-145] L. Liu, Shenzhen Univ. (China) and Anhui Institute of Optics and Fine Mechanics (China); Y. Shao, J. QU, H. Li, B. Guo, Shenzhen Univ. (China); W. Liu, Anhui Institute of Optics and Fine Mechanics (China); H. Niu, Shenzhen Univ. (China)

7280 1D Design and implementation of a 2-D endoscopic optical fiber scanner [7280-158] Z. Liu, L. Fu, F. Gao, X. Zhang, Huazhong Univ. of Science and Technology (China)

$72801 \mathrm{E} \quad$ Cellular model studies of brain-mediated phototherapy on Alzheimer's disease [7280-133] L. Zhu, T. C.-Y. Liu, South China Normal Univ. (China); B. Hu, South China Normal Univ. (China) and Pingdingshan College of Education (China); X.-Y. Li, South China Normal Univ. (China); Y.-Q. Wang, South China Normal Univ. (China) and Institute of Psychology (China)

$7280 \mathrm{IF} \quad$ Computation and visualization of spreading depression based on reaction-diffusion equation with recovery [7280-141]

H. Ding, S. Chen, S. Zeng, S. Zeng, Q. Liu, Q. Luo, Huazhong Univ. of Science and Technology (China)

7280 1G A novel limited-view photoacoustic reconstruction algorithm combined iteration with back-projection calculation [7280-84]

S. Ma, H. Guo, South China Normal Univ. (China)

$72801 \mathrm{H} \quad$ Study on the SPR responses of various DNA probe concentrations by parallel scan spectral SPR imaging [7280-156]

S. Ma, L. Liu, Tsinghua Univ. (China); W. Lu, Third Military Medical Univ. (China); Y. Zhang,

Y. He, J. Guo, Tsinghua Univ. (China)

$728011 \quad$ Evaluation of mitochondrial NADH and brain functions during retraction using a multiparametric monitoring system [7280-99]

E. Barbiro-Michaely, H. Arnon, A. Mayevsky, Bar-llan Univ. (Israel)

$72801 \mathrm{~J}$ The role of nitric oxide in the ischemic brain evaluated by spectroscopic monitoring of mitochondrial NADH, microcirculatory blood flow, and $\mathrm{HbO}_{2}$ [7280-107]

E. Eibeshitz, E. Barbiro-Michaely, A. Mayevsky, Bar-Ilan Univ. (Israel)

$72801 \mathrm{~K}$ Classification of tissue pathological state using optical multiparametric monitoring approach [7280-108]

H. Kutai-Asis, I. Kanter, E. Barbiro-Michaely, A. Mayevsky, Bar-llan Univ. (Israel)

$72801 \mathrm{~L} \quad 3-\mathrm{D}$ velocity vector measurement using optical Doppler tomography [7280-20]

J. Meng, Z. Ding, K. Wang, Y. Zhu, T. Wu, Zhejiang Univ. (China) 
$72801 \mathrm{M}$ Optical coherence tomography reveals in vivo cortical structures of adult rats in response to cerebral ischemia injury [7280-89]

Y. Ni, Z. Guo, S. Shu, X. Bao, South China Normal Univ. (China)

$72801 \mathrm{~N}$ Thermoacoustic and photoacoustic imaging of biological tissue with different contrasts and properties [7280-82]

L. Nie, H. Guo, South China Normal Univ. (China)

728010 Numerical study on dynamic properties of the optothermal effect on the spatial distribution within human skin [7280-120]

D. Peng, Jimei Univ. (China) and Fujian Normal Univ. (China); H. Li, Fujian Normal Univ.

(China); J. Chen, Jimei Univ. (China)

7280 IP A discussion on validity of the diffusion theory by Monte Carlo method [7280-127]

D. Peng, Jimei Univ. (China) and Fujian Normal Univ. (China); H. Li, S. Xie, Fujian Normal Univ. (China)

$72801 Q$ Research on biochemical spectrum denoising based on a novel wavelet threshold function and an improved translation-invariance method [7280-33]

Z. Ren, G. Liu, L. Zeng, Z. Huang, Jiangxi Science and Technology Normal Univ. (China);

S. Huang, Jiangxi Agricultural Univ. (China)

7280 is Cisplatin-induced Casepase-3 activation in different tumor cells [7280-162]

H. Shi, X. Li, T. SU, Y.-H. Zhang, Huazhong Univ. of Science and Technology (China)

$72801 \mathrm{~T}$ Effect of the prosurvival protein MCL-1 on photodynamic therapy induced apoptosis [7280-106]

J. Song, Y. Li, Y. Wei, South China Normal Univ. (China)

$72801 \mathrm{U}$ Combining isothermal rolling circle amplification and electrochemiluminescence for highly sensitive point mutation detection [7280-88]

Q. Su, X. Zhou, South China Normal Univ. (China)

7280 IV A simultaneous photoacoustic tomography imaging technique in multilayer media [7280-111]

X. Chen, Z. Tang, Y. He, H. Liu, South China Normal Univ. (China)

7280 IW The application of PSD in the faultage $x$-ray photograph system [7280-37]

S. Wang, T. Li, Shandong Univ. of Technology (China)

$72801 \mathrm{~F}$ Full range complex spectral domain optical coherence tomography based on spatial sinusoidal phase modulation [7280-56]

K. Wang, Z. Ding, J. Meng, M. Chen, Zhejiang Univ. (China)

7280 1Y Real-time monitoring BimL interacting with Bcl-xL during UV-induced apoptosis [7280-118] $X$. Wang, S. Wu, South China Normal Univ. (China)

$72801 \mathrm{Z}$ Five-color fluorescent imaging in living tumor cells [7280-160]

L. Wang, J. Yang, J. Chu, Q. Luo, Z. Zhang, Huazhong Univ. of Science and Technology

(China) 
728020 Real-time monitoring of singlet oxygen in photodynamic therapy with chemiluminescence [7280-35]

Y. C. Wei, L. Y. Yang, J. X. Song, South China Normal Univ. (China)

728021 Superficial microcirculation flow measurement using polarized light [7280-13]

J. Wu, Tongji Univ. (China); S. P. Morgan, The Univ. of Nottingham (United Kingdom); Y. Xiao, Tongji Univ. (China)

728022 Photorejuvenation observation based on two photon microscopy [7280-34]

S. Wu, H. Li, Z. Xiao, S. Xie, Fujian Normal Univ. (China)

728023 Measuring dynamics of Caspase-9 activity in living cells using FRET technique during apoptosis induced by high fluence low-power laser irradiation [7280-110]

S. WU, L. Huang, X. Sun, J. Chu, South China Normal Univ. (China)

728024 The mensuration of delayed luminescence on ginseng [7280-32]

F. Xiang, Langfang Normal College (China); H. Bai, G. Tang, Nankai Univ. (China)

728025 Nondestructive quantification of permeability of hyperosmotic agent in normal and tumor tissues [7280-52]

H. Xiong, Z. Guo, C. Zeng, South China Normal Univ. (China); L. Wang, Harbin Institute of Technology (China); Y. He, Tsinghua Univ. (China); S. Liu, South China Normal Univ. (China)

728026 Noninvasive detection of gas exchange rate by near infrared spectroscopy [7280-139] G. XU, Z. Mao, Wuhan Institute of Physical Education (China); B. Wang, Huazhong Univ. of Science and Technology (China)

728027 A new method of medical image fusion based on nonsubsampled contourlet transform [7280-66]

X. XU, X. Zhang, D. Zhang, Xi'an Jiaotong Univ. (China)

728028 Biometric recognition using digital curvelet transform and BP neural network [7280-67]

X. XU, X. Zhang, D. Zhang, Xi'an Jiaotong Univ. (China)

728029 Study of $x$-ray CCD image sensor and application [7280-38]

S. Wang, T. Li, Shandong Univ. of Technology (China)

7280 2A A novel method of identification of high-yield crop cultivars using correlation between delayed fluorescence and photosynthesis capacity [7280-80]

J. Wang, W. XU, Y. Li, Dalian Maritime Univ. (China); L. Zhang, South China Normal Univ. (China)

$72802 \mathrm{~B}$ In vivo mouse brain tomography by fast dual-scanning photoacoustic imaging system based on array transducer [7280-87]

S. Yang, D. Xing, South China Normal Univ. (China)

7280 2C Enhancement of photodynamic therapy effect by temporally inhibiting infarction with anticoagulant heparin [7280-90]

L. Yang, H. Zhao, South China Normal Univ. (China) 
7280 2D Morphologic characteristics of processes of nucleus pulposus cells in adult human intervertebral disc [7280-151]

X. Liu, X. Wu, Tongji Medical College, Huazhong Univ. of Science and Technology (China);

L. Hui, Shuiguo Lake Middle School (China); W. Xu, X. Liu, S. Yang, Tongji Medical College,

Huazhong Univ. of Science and Technology (China)

$72802 \mathrm{E} \quad$ Imaging of hemoglobin oxygen saturation using confocal photoacoustic system with three optical wavelengths [7280-94]

G. Yin, Y. Yuan, South China Normal Univ. (China)

$72802 \mathrm{~F}$ Design of a portable noninvasive photoacoustic glucose monitoring system integrated laser diode excitation with annular array detection [7280-115]

L. Zeng, G. Liu, Jiangxi Science and Technology Normal Univ. (China); D. Yang, Hunan Univ. of Technology (China); Z. Ren, Z. Huang, Jiangxi Science and Technology Normal Univ.

(China)

72802 Analysis of microscopy of fluorescence effect of weak laser acting on living biomolecule [7280-54]

C. Zhang, Honghe Univ (China); L. Xu, Yunnan Normal Univ. (China); L. Hong, Honghe Univ. (China); G. Li, Yunnan Normal Univ. (China); L. Zhou, Kunming Univ. of Science and Technology (China) and Honghe Univ. (China)

$72802 \mathrm{H} \quad$ Experimental research on the effects of different lasers acting on yeast and corresponding theoretical analyses [7280-55]

C. Zhang, Honghe Univ. (China); L. Xu, G. Li, Yunnan Normal Univ. (China); L. Hong, Honghe Univ. (China); L. Zhou, Kunming Univ. of Science and Technology (China) and Honghe Univ. (China)

$728021 \quad$ A preliminary physiological and biochemical study on He-Ne laser mutation breeding of Erigeron breviscapus [7280-62]

B. Gao, C. Zhang, H. Li, L. Lin, R. Zhang, T. Zhou, J. Tian, J. Zhang, Honghe Univ. (China)

$72802 \mathrm{~J}$ Study on the modification of measured wavefront aberration data for customized visual correction [7280-64]

M. Liu, Y. Zhang, Z. Zhang, Hebei Univ. of Technology (China); W. Quan, Jilin Univ. (China);

L. An, Hebei Univ. of Technology (China)

$72802 \mathrm{~K}$ Theoretical analysis of $\mathbf{x}$-ray CT phase-contrast imaging [7280-85]

S. Feng, S. Liu, X. Zhang, Univ. of Shanghai for Science and Technology (China)

$72802 \mathrm{~L} \quad$ Manipulating multiparticles simultaneously with tapered-tip single fiber optical tweezers [7280-159]

Y. Zhang, Z. Wu, Z. Liu, J. Yang, L. Yuan, Harbin Engineering Univ. (China)

$72802 \mathrm{M}$ Multifluorescence emission of several novel phthalocyanines as potential photodynamic diagnosis materials [7280-1 12]

Y.-S. Park, J.-W. Woo, Sangmyung Univ. (Korea, Republic of); P. Zhao, Sangmyung Univ. (Korea, Republic of) and Tsinghua Univ. (China); Z. Chen, F. Zhang, Tsinghua Univ. (China) 
$72802 \mathrm{~N} \quad$ Using low-frequency ultrasound to improve the optical clearing of porcine skin [7280-51] H. Zhong, Z. Guo, H. Wei, Z. Zhang, C. Zeng, J. Zhai, South China Normal Univ. (China); Y. He, Tsinghua Univ. (China)

728020 Sensitive detection of point mutation by electrochemiluminescence and DNA ligase-based assay [7280-91]

H. Zhou, B. Wu, South China Normal Univ. (China)

$72802 \mathrm{P} \quad$ Optoelectronic monitoring of neural activity [7280-150]

X. Liu, T. Quan, W. Zhou, Huazhong Univ. of Science and Technology (China)

$72802 \mathrm{C}$ Comparative study of reflectance spectra for human Laogong acupoint and non-acupoint tissues irradiated by laser [7280-78]

Z. Zhang, Z. Guo, H. Wei, H. Zhong, South China Normal Univ. (China); H. Yang, S. Xie, Fujian Normal Univ. (China); S. Liu, South China Normal Univ. (China)

Author Index 
Downloaded From: https://www.spiedigitallibrary.org/conference-proceedings-of-spie on 26 Apr 2023

Terms of Use: https://www.spiedigitallibrary.org/terms-of-use 


\title{
Conference Committees
}

\author{
Honorary Chairs
}

Britton Chance, University of Pennsylvania (United States)

Bingkun Zhou, Tsinghua University (China)

\section{Conference Chairs}

Qingming Luo, Huazhong University of Science and Technology (China)

Lihong V. Wang, Washington University in St. Lovis (United States)

Valery V. Tuchin, Saratov State University (Russian Federation)

Conference Secretariat

Hua Shi, Huazhong University of Science and Technology (China)

Advisory Committee

Sydney Brenner, Salk Institute (United States)

Howard Chen, K\&L Gates (United States)

Jing Cheng, Tsinghua University (China)

Paul Ching-Wu Chu, The Hong Kong University of Science and

Technology (Hong Kong, China)

Aaron Ciechanover, Technion-Israel Institute of Technology (Israel)

A. Stephen Dahms, Alfred E. Mann Foundation for Biomedical Engineering (United States)

Da Hsuan Feng, National Cheng Kung University (Taiwan, China)

Steven R. Goodman, SUNY Upstate Medical University (United States)

Barry Halliwell, National University of Singapore (Singapore)

John Hart, The University of Texas at Dallas (United States)

George Radda, A*STAR-Agency for Science, Technology and Research (Singapore)

Zihe Rao, Nankai University (China)

A. Dean Sherry, The University of Texas at Dallas (United States)

Ruey-Jen Sung, Stanford University (United States)

Bruce Tromberg, University of California, Irvine (United States)

Fujia Yang, Nottingham University (United Kingdom)

Jianquan Yao, Tianjin University (China)

Yixin Zeng, Sun Yat-sen University Cancer Center (China)

Baoyong Zheng, Hua Wei Technologies Corporation, Inc. (China) 
Program Committee

Wei R. Chen, University of Central Oklahoma (United States)

Wei R. Chen, Yale University (United States)

Zhongping Chen, University of California, Irvine (United States)

Arthur Chiou, National Yang-Ming University (Taiwan, China)

Zhihua Ding, Zhejiang University (China)

Zheng Huang, University of Colorado Health Sciences Center (United States)

Steven L. Jacques, Oregon Health \& Science University (United States)

Huabei Jiang, University of Florida (United States)

Xingde Li, University of Washington (United States)

Hong Liu, University of Oklahoma (United States)

Zuhong Lu, Southeast University (China)

Hui Ma, Tsinghua University (China)

Dennis L. Matthews, University of California, Davis (United States)

Avraham Mayevsky, Bar llan University (Israel)

Igor V. Meglinski, Cranfield University (United Kingdom)

Stephen P. Morgan, University of Nottingham (United Kingdom)

Shoko Nioka, University of Pennsylvania (United States)

Alexander V. Priezzhev, M.V. Lomonosov Moscow State University

(Russian Federation)

Yuwen Qin, National Natural Science Foundation of China (China)

Alexander Savitsky, A.N. Bach Institute of Biochemistry (Russian

Federation)

Q. Charles Su, Illinois State University (United States)

Mamoru Tamura, Hokkaido University (Japan)

Sergey Ulyanov, Saratov State University (Russian Federation)

Andong Xia, Institute of Chemistry, Chinese Academy of Sciences (China)

Shusen Xie, Fujian Normal University (China)

Da Xing, South China Normal University (China)

Kexin Xu, Tianjin University (China)

Xincheng Yao, University of Alabama at Birmingham (United States)

Haishan Zeng, BC Cancer Research Centre (Canada)

Zhenxi Zhang, Xi'an Jiaotong University (China)

Gang Zheng, University of Toronto (Canada)

Organizing Committee

Shaoqun Zeng, Chair, Huazhong University of Science and

Technology (China)

Ling Fu, Huazhong University of Science and Technology (China)

Hui Gong, Huazhong University of Science and Technology (China)

Pengcheng Li, Huazhong University of Science and Technology (China)

Bifeng Liu, Huazhong University of Science and Technology (China) 
Zhihong Zhang, Huazhong University of Science and Technology (China)

Yuandi Zhao, Huazhong University of Science and Technology (China) Dan Zhu, Huazhong University of Science and Technology (China) 
Downloaded From: https://www.spiedigitallibrary.org/conference-proceedings-of-spie on 26 Apr 2023

Terms of Use: https://www.spiedigitallibrary.org/terms-of-use 


\section{Introduction}

The Seventh International Conference on Photonics and Imaging in Biology and Medicine (PIBM 2008), combined with the Photonics and Optoelectronics Meetings (POEM 2008), was held 24-27 November 2008 at Wuhan Science \& Technology Convention \& Exhibition Center, Wuhan, P.R. China. This proceedings volume contains selected papers from the oral and poster presentations delivered at the conference.

PIBM is the largest international biomedical photonics conference series in Asia. It was initiated in 1999 at HUST and was held bi-yearly until 2006. After being held three times in Wuhan (1999, 2001, and 2003), it was hosted once in Tianjin (2005), and then went back to Wuhan, and has been held there yearly since 2006. PIBM is designed to bring together scientists, engineers, and clinical researchers from a variety of disciplines engaged in applying optical science, photonics, and imaging technologies to problems in biology and medicine. The scope of this conference ranges from basic research to instrumentation engineering, to biological and clinical studies. PIBM is recognized as one of the largest and most comprehensive international conferences in China, and represents the highest level of international research in this field. In the past nine years, five volumes of conference proceedings with a total of 513 papers were published by SPIE; in 2007, one volume with 75 papers was published by World Scientific Publishing Company. Each year, more and more young researchers present and exchange their innovative ideas in this friendly and professional event, making PIBM an unforgettable annual meeting in Wuhan.

This year, PIBM attracted distinguished scholars in the biomedical photonics and imaging field from countries around the world, such as the United States, United Kingdom, Russia, Canada, Israel, Singapore, Japan, Italy, Republic of Korea, and China. The invited speakers included:

Britton Chance, Univ. of Pennsylvania (USA)

Yu Chen, Univ. of Maryland (USA)

Zhongping Chen, Univ. of California, Irvine (USA)

Jing Cheng, Tsinghua Univ. (China)

Zhen Cheng, Stanford Univ. (USA)

Frank Y. S. Chuang, Univ. of

California, Davis (USA)

Aaron Ciechanover (2004 Nobel Laureate), Technion-Israel Institute of Technology (Israel)
Chen-Yuan Dong, National Taiwan Univ. (Taiwan, China)

Congwu Du, Brookhaven National Lab. (USA)

Steven R. Goodman, SUNY Upstate Medical Univ. (USA)

Weiping Han, A*STAR-Agency for Science, Technology and Research (Singapore)

Chang-Deng Hu, Purdue Univ. School of Pharmacy (USA) 
Zheng Huang, Univ. of Colorado at Denver and Health Sciences Ctr. (USA)

Zhiwei Huang, National Univ. of Singapore (Singapore)

Steven L. Jacques, Oregon Health \& Science Univ. (USA)

Yong-qing Li, East Carolina Univ. (USA)

Chengyi Liu, South China Normal Univ. (China)

Zuhong Lu, Southeast Univ. (China)

Qingming Luo, Huazhong Univ. of Science and Technology (China)

Avraham Mayevsky, Bar-llan Univ. (Israel)

Steve P. Morgan, Univ. of Nottingham (UK)

Shoko Nioka, Univ. of Pennsylvania (USA)

Brian M. Salzberg, Univ. of Pennsylvania (USA)
Q. Charles Su, Illinois State Univ. (USA) Ruey-Jen Sung, Stanford Univ. (USA)

Mamoru Tamura, Hokkaido Univ. (Japan)

Bruce J. Tromberg, Univ. of California, Irvine (USA)

Valery V. Tuchin, Saratov State Univ. (Russia)

Lihong V. Wang, Washington Univ. in St. Louis (USA)

Ruikang K. Wang, Oregon Health \& Science Univ. (USA)

Xincheng Yao, Univ. of Alabama at Birmingham (USA)

Haishan Zeng, BC Cancer Research Ctr. (Canada)

Dongping Zhong, The Ohio State Univ. (USA)

Ming-Qiang Zhu, Hunan Univ. (China)

The major topics covered at the conference and presented in this volume include:

- Tissue optics and diffuse optical Imaging,

- Optical molecular imaging,

- Multiphoton microscopy in biomedical sciences,

- Photonic therapeutics, diagnostics, and instrumentation, and

- Multimodal and hybrid biomedical imaging.

The conference received 165 submitted abstracts. This volume includes a selection of 2 invited papers, and 92 contributed papers. The conference elected four best student paper awards, which were given to the student participants whose posters were recognized as excellent and who attended a competition among the oral presenters. The evaluation was carried out by a council of seven members: Avraham Mayevsky (chair), Zheng Huang (chair), Zhongping Chen, Frank Chuang, Shoko Nioka, Valery Tuchin, and Haishan Zeng. Three Optical Hot Topic Workshops were conducted on molecular imaging and brain imaging, including a "face to face" with the Editors in Chief of three world-class peerreviewed journals.

The conference secretariat and local organizing committee deserve great appreciation for creating a smoothly run and productive conference with comprehensive and instructive lectures, and informative posters representing 
innovative work. The faculties and students from Britton Chance Center for Biomedical Photonics were dedicated in the reception and service work throughout the conference. It is a pleasure to thank all of them for their efficient and hard work. We are grateful for the financial support from 111 Project (B07038) and 863 Project (2006AA02Z343, 2006AA020801), as well as the organization and coordination from Wuhan National Laboratory for Optoelectronics and Huazhong University of Science and Technology.

Finally, we would like to thank all of the authors for their contributions to PIBM 2008 and all of the members of the committees for their cooperation and time spent reviewing submissions. We especially thank the advisory committee members Howard Chen, Jing Cheng, Paul Ching-Wu Chu, Aaron Ciechanover, Steven R. Goodman, Ruey-Jen Sung, Bruce Tromberg, and Jianquan Yao for their on-site participation and their strong contributions to the conference.

\section{Qingming Luo Lihong V. Wang Valery V. Tuchin}


Downloaded From: https://www.spiedigitallibrary.org/conference-proceedings-of-spie on 26 Apr 2023

Terms of Use: https://www.spiedigitallibrary.org/terms-of-use 